\title{
The Promotion Measures for Graduates to be Self-employed in Foreign Countries and Its Inspiration to China
}

\author{
Ling Wang ${ }^{1, a^{*}}$, Daying Liü ${ }^{2, b}$, Wenbi Zhu ${ }^{3, c}$ and Xiaoqian Zhang ${ }^{4, d}$ \\ ${ }^{1}$ The department of students' affairs, Tianjin Agricultural University, Tianjin, China \\ ${ }^{2}$ The department of basic science, Tianjin Agricultural University, Tianjin, China \\ ${ }^{3}$ The department of teaching affairs, Tianjin Agricultural University, Tianjin, China \\ ${ }^{4}$ The College of agronomy \& resources and environment, Tianjin Agricultural University, Tianjin, \\ China
}

awangling1515@126.com, bliudaying03@163.com, 'zhuwenbi@tjau.edu.cn, d764129464@qq.com

Keywords: College students; Promotion measures; Self-employed; Inspiration

\begin{abstract}
Faced with the current severe employment situation, the independent undertaking for graduates is an available method of relieving employment pressure. However, compared with foreign countries, with a shorter period of history, there is lack of perfect system and scientific mechanism, and deficiency of good social atmosphere in China. Herein, according to completely analyzing the existing problems in China and the promotion measures in foreign countries, the promotion suggestions and strategies for Chinese graduates to start their own undertaking are proposed.
\end{abstract}

\section{Introduction}

Using the knowledge, the talent, the technology and the various ability they learned, and through the efforts of individuals and organizations, the entrepreneur start their own undertaking in a limited environment by self-financing, technology stocks and seeking cooperation, and strive to achieving the innovation, seeking opportunities, growing and value creation, such as setting up the shop, the factories, the company, business investment, production and operation activities [1]. Independent entrepreneurship provides college students with the most creative and dynamic path of innovation beyond employment and further education.

In recent years, the annual number of graduates is increasing year by year, because of the expansion of university enrollment. for example, 6 million 800 thousand in 2012, 6 million 990 thousand in 2013, 7 million 270 thousand in 2014, 7 million 490 thousand in 2015, 7 million 560 thousand in 2016, including the previous unrealized-employment college students, the employment situation is still very severe. The independent undertaking is one of the most effective ways to solve the problem of the employment of university students [2]. In 2015, Premier Keqiang Li proposed "public business, the new ideas of innovation" in the government work report. The entrepreneurship has become a hot topic in current college students. Currently, Chinese students get stronger and stronger support from the universities, the government and the public. However, there are still many problems.

\section{Main Problems Faced by the Chinese Students in Their Own Business}

According to statistics, 25\% graduates in United States and 15\% in Japan the college students choose to start their own undertaking, respectively. The data of independent undertaking in Chinese college students after graduation are $2.3 \%, 2.9 \%, 3 \%$, respectively, nearly three years [3]. Therefore, the gap is still relatively large and there are some problems to be solved.

Lack of Risk Awareness and Low Entrepreneurial Enthusiasm. From the entrepreneurial point of view, anti-risk awareness is essentially fighting spirit. Lack of risk awareness in contemporary college students are derived from Chinese thousands of years of cultural accumulation of negative aspects. The thought "small rich is good" is very strong in Chinese people, "avoid risk" awareness is very high, therefore, they are unwilling to start a business, because of thought lazy, no pioneering 
spirit, and lack of independent consciousness. In addition, the examination oriented education, to a certain extent, also denied the students independent development consciousness, the students generally shows poor psychological quality, not bearing the pressure of society, the fear of challenge and social responsibility, and the deficiency of the necessary business confidence [4].

Lack of Entrepreneurial Knowledge and Ability. Entrepreneurship is a complex process. It requires the entrepreneurs not only to know enough about the project, but also to have rich knowledge of enterprise registration, management, marketing and finance, and other aspects of the mode of operation of the industry. It is also necessary to be familiar with the national macro policy, legal concept, the credibility and other problems. However, in the four years of study life, students spend most of the time and energy on the learning of professional knowledge and the cultivation of professional skills, it is difficult to have direct and indirect experience on entrepreneurship, entrepreneurial knowledge is generally limited to "empty talk", thus, students and companies operating will definitely encounter various unforeseen problems and lead to entrepreneurial difficulties [5].

Lack of Entrepreneurial Start-up Capital Lack of funds is a major problem for college students' entrepreneurship. At the current situation, the main source of funds is relatives and friends, banks or venture capital firms. After all, the capital that friends and relatives can provide is limited, college students are difficult to have enough capital, therefore, social financing or interest free loans is the inevitable choice. However, because of college students venture's the greater risk, relatively lower reputation, it is difficult for students to borrow the money from the bank and obtain the necessary funds. There are some widespread problems in the process of entrepreneurship financing, such as confusing risk investment, unattainable commercial loans, a fraction of government support funds, etc. These factors seriously restrict college students' entrepreneurship [6].

Imperfect and Incomplete Entrepreneurship Environment To promote college students' entrepreneurship is called up in recent years in China, therefore, the overall entrepreneurship policy and support service system is not perfect and complete, low degree of protection makes many college students give up the entrepreneurial opportunities in the society because of fear of failure or too high start-up costs. College Students' undertaking security is mainly due to the poor implementation of national policies and regulations. In addition, at present, compared to high-tech undertaking, the service undertaking is more quantity, generally lower level, and less proportion of success, no thick entrepreneurial atmosphere and the developing fiery scenes is appeared, thus, it is difficult to excite the students' entrepreneurial interest [7].

\section{Measures for Foreign Students to Promote Starting Their Own Business}

Paying Great Attention to the Cultivation of Students' Entrepreneurial Consciousness. The German government requires universities, high schools, vocational schools to offer the entrepreneurship training courses, ensure that the students get firstly acquainted with the knowledge of entrepreneurship. At the same time, the government and financial research institutions jointly supply some entrepreneurial opportunities in the school, so that students can try to open their own companies, contact and familiar with business management and business knowledge. In the young-entrepreneurs project launched by the German Economic Research Institute, students can build up micro companies under the guidance of the school. These companies are as running as the regular companies in the market environment. Therefore, good companies succeed and bad ones do not. Meanwhile, the government is committed to creating a campus entrepreneurial atmosphere, holding regular lectures in some universities, and inviting the business community to participate in [8].

Excellent Entrepreneurship Education System At least $45 \%$ of the universities are provided with one or more courses of entrepreneurship education in Britain. In order to enable students to obtain approximate entrepreneurial experience, the group interactive teaching mode is used, and more real business activities are contacted. The British Institute of higher education provides the teaching materials of entrepreneurial skills for universities, and provides academic support for entrepreneurship education by using various groups of the society and the work of various academic 
centers. Southborough University, ranking sixth in UK, students' innovation and entrepreneurship scholarship winners will receive an award of business guidance, including intellectual property laws and regulations, public relations and marketing proposals, business plans and financial applications, good risk funds, etc. More than 500 colleges and universities have set up entrepreneurship courses in United States. Swedish entrepreneurship education has been available in the national education system, covering the junior high school, senior high school, undergraduate education, even the graduate education. At present, Sweden's primary and secondary schools have developed a large number of entrepreneurship education courses and games, so that students are getting interested in innovation, competition, cost and profit, and other important concepts from an early age. Swedish universities not only undertake the task of offering entrepreneurship education for their students, but also launch a large number of social entrepreneurship training programs.

Complete Credit System To support young people to start their own business, developed countries have their own credit plans and funds [9]. The youth entrepreneurship programs, for example, the 1983 British Prince fund launched in the UK, through joint business and social forces, can provide advice and funding for youth entrepreneurship, technology, and network support. The program helps 5000 young British entrepreneurs per year on average, and the entrepreneurial success rate of is more than $60 \%$. Developed venture capital and credit systems also help college entrepreneurs solve financial difficulties. In the absence of collateral, on the strength of a good business plan, the students are also likely to lend money from the bank. In addition, College students can also use credit card loans to start business in US. For example, YouTube founder Shijun Yang has been using a credit card to pay the server fees up to $\$ 18,000$ per month.

Develop a Variety of Entrepreneurial Competition The "business plan contest", aimed at American College Students, is a successful model. The participating college students need to write a business feasibility report on a new products or services with particular market prospects, and select the betters reviewed by academics and business celebrities. In the participation of the business community, some of the winning feasibility report finally can win the venture capital. Currently, more than 20 universities, including Massachusetts Institute of Technology, Stanford University and other world-class universities, hold the business plan contest every year in United States. A batch of entrepreneurs can achieve more exercise and growth in the contest. Venture capitalists swarmed into the university campus, looking for a technology leader in the future. The students winning the contest mostly become a leader in the American high-tech enterprises [10].

\section{It's Inspiration to China}

Continue to Strengthen Government Support to reduce the Threshold of Independent Entrepreneurship. According to the graduates' needs and local demand, national and local governments should be appropriate to relax the entrepreneurial market access conditions of college students, even to open up entrepreneurship green channel for them. On the other hand, the governments continue to introduce preferential policies related to their own entrepreneurship, and highlight the convenience and practicality of independent entrepreneurship while developing entrepreneurial policies. For example, complete cancellation of college graduates limit settled, increasing small loans, offer free tax preferential policies, no the relevant expenses and provide business base, etc. [11].

Promote Entrepreneurship and Create Entrepreneurial Atmosphere. Good entrepreneurial atmosphere can inspire college students to start their own business. The government also should strengthen the policy support and guide so that encourage students to choose independent entrepreneurs; the Communist Youth League, the Youth Federation and other organizations should give the typical entrepreneurship students a special praise, the successful entrepreneurship experience of college students should be attracted widespread publicity; the media should take advantage of the success typical entrepreneurial, and strongly promote the entrepreneurial spirit, namely, "unremitting self-improvement, self-perseverance, self-struggle". A positive and relaxed public environment is build-up, reasonable and objective evaluation is given on entrepreneurship. We encourage and support the college students who are willing to start their own business. The good atmosphere that 
proud and support of entrepreneurship is established in the whole society.

Enhance the Construction of Financial Security System. The perfect financial security system can increase the success rate of College Students' self - employment and avoid their worries. For example, the College Students' Entrepreneurship fund is constituted, it can provide financial support to the students that with the greatest chances for success through the professional assessment; improve the interest of small loan amount, extend the repayment period; establish venture capital investment fund. For the business students who are suffered business failure and unable to repay maturing microfinance loans, they can turn to the venture capital investment fund and are partly reimbursed by it. Therefore, not only eliminating the concerns from financial institutions, but also easing the economic pressure on college students suffered entrepreneurship failure. It also can implement the return preferential tax and local tax policy for college graduates.

Perfecting the Curriculum System of Entrepreneurship Education. Curriculum is an important way for students to obtain knowledge and information directly. The entrepreneurship education should be adopted in the education system of colleges and universities, the course of entrepreneurship education should be established, the teachers of entrepreneurship education should be cultivated, and the teaching materials of enterprise education should be prepared. In the course of teaching, case analysis, business forums, lectures, entrepreneurs from a variety of teaching methods can be used to motivate students' entrepreneurial awareness and passion. In addition, the preferential trade policies, industry characteristics, industry prospects analysis of content and etc., are introduced to the curriculum to build comprehensive industry entrepreneurship education system, give students an objective and comprehensive understanding before the start and improve the social adaptation ability.

Further Develop Entrepreneurial Practice. Only taking into account of entrepreneurial ideas and the practices, entrepreneurship will get a good effect. Therefore, colleges and universities should pay more attention to not only the theoretical teaching of entrepreneurship education, but also offering the opportunity to practice. For example, regular business meetings can be organized, and some famous occupation managers of social entrepreneurs, successful entrepreneurs are invited. Thus, the students can communicate with them close together. The entrepreneurs can share the experience of successful entrepreneurial; through holding entrepreneurship competition and simulating entrepreneurship situation, the students will combine entrepreneurial ideas and classroom knowledge, exercise the ability of students' personal and team entrepreneurship. It also should do the entrepreneurship education base construction well, choose some large and medium-sized enterprises as the entrepreneurship education practice base, and encourage qualified universities to build the innovation centers or business parks.

\section{Summary}

In conclusion, compared with the developed countries, Chinese college students' independent entrepreneurship is lagging behind, and different countries have different policies to promote their own entrepreneurship. For China, in order to promote entrepreneurship development, a variety of policies which target to improve and develop entrepreneurship need to be put forward, according to the national conditions, so that can solve the low rate of self-employment fundamentally and ease the employment pressure on university students.

\section{References}

[1] T. H. Gindling, D. Newhouse, Self-employment in the developing world, World Development 56 (2014) 313-331.

[2] S. G. Walter, K. P. Parboteeah, A. Walter, University departments and self-employment intentions of business students: a cross - level analysis, Entrepreneurship Theory and Practice 37(2013) 175-200. 
[3] F. S. Gohmann, Institutions, latent entrepreneurship, and self-employment: an international comparison, Entrepreneurship Theory and Practice 36 (2012) 295-321.

[4] W. Du, A preliminary analysis of the advantages and disadvantages of college students, China University Students Career Guide 18 (2014) 60-65.

[5] X. Qian, The research of undergraduates'self-employment, Dissertation, Jilin University of Finance and Economics, 2013.

[6] T. Kuang, Y. Guo, N. Zhou, Reason and countermeasure: college student's entrepreneurship funding difficulties, Journal of Xichang College (Social Science Editon) 26 (2014) 123-125.

[7] P. Patrick, Entrepreneurship education and entry into self-employment among university graduates, World Development 77 (2016) 311-327.

[8] J. M. Millán, E. Congregado, C. Román, determinants of self-employment survival in Europe, Small Business Economics 38 (2012) 231-258.

[9] S. Natalie, F. Lourenco, eds., Entrepreneurship, self-employment and retirement, Springer, 2015.

[10]F. Paolo, L. Haywood, Entrepreneurship versus joblessness explaining the rise in self-employment, Journal of Development Economics 118 (2016) 245-265.

[11]F. Niu, Shandong government's policy research on supporting university students' self-employment, Dissertation, Shandong University of Finance and Economics, 2016. 